\title{
EFFECT OF CORPORATE GOVERNANCE (WOMAN'S EXECUTIVE BOARD), COMPANY SIZE AND LEVERAGE ON PROFIT MANAGEMENT
}

\author{
Siska Octaviani ${ }^{1}$ \\ Ely Kartikaningdyah ${ }^{2}$ \\ Program Studi Akuntansi Manajerial, Politeknik Negeri Batam \\ Jl. Ahmad Yani, Batam Centre, Batam 29461, Indonesia \\ 1) E-mail: siska.octaviani95@gmail.com \\ ${ }^{2)}$ E-mail: ely@polibatam.ac.id
}

\begin{abstract}
The purpose of this study was to measure the effect of corporate governance (female membership), company size and leverage on profits in companies on the Indonesia Stock Exchange (BEI) in 2012-2016. The variables used in this study are size variables, and the variable used in this study is earnings management that uses discretionary accruals using the Dechow et. Al. (1995). Withdrawal of the research sample using purposive sampling method that gets 225 samples of manufacturing companies and data which are data panels. This study conducts multiple regression with multiple regression with Eviews version 10. The results of this study indicate that the female board of directors who are insightful with earnings management when the female board of commissioners, women's audit committee, company size, and leverage do not affect earnings management.
\end{abstract}

Keyword: corporate governance, Earnings Management, leverage, discretionary accruals. 


\section{Pendahuluan}

Go public companies are companies that have a majority of their shares owned by the public through the stock exchange. The company has an obligation to present financial statements in accordance with the requirements set by the competent authority in Indonesia, namely the Financial Services Authority (OJK). The purpose of financial statements is to provide useful information in order to assess management's ability to use company resources effectively to achieve the company's main objectives (Belkaoui, 2006).

The financial statements consist of statements of financial position, income statement, cash flow statement, statement of changes in equity, and notes to financial statements. In general, all parts of the financial statements are important and necessary for decision making. However, most users of financial statements are more focused on earnings information contained in the income statement without regard to the procedures used to generate the profit or loss.

To minimize the occurrence of earnings management practices by company management, a mechanism for good corporate governance is needed in this case the control and management of the company. (Corporate Governance) is an effort made by all parties with an interest in the company to run its business properly in accordance with their respective rights and obligations (Arifin, 2005). Corporate Governance also provides a structure that facilitates the determination of goals of a company, and as a means to determine performance monitoring techniques (Darmawati, Khomsiyah and Rahayu, 2004)

In corporate governance, management used in reporting includes directors, board of commissioners, and audit committees. The board of directors is one of the parties responsible and managing finances. Board of Commissioners and audit committee. The existence of women in top management is one of the problems of corporate governance that is developing in recent years. The existence of women in top management is an interesting thing to study because there are still differences in this. Through the 2013 Ministry of
Women's Empowerment and Child Protection book, Indonesia has gender inequality one of them in terms of employment.

Other factors beyond corporate governance that can affect earnings management are company size and leverage. According to Herni and Susanto (2008) large companies lack the motivation to make income smoothing (earnings management) compared to small companies because large companies are more careful and viewed critically by investors and outside parties. Leverage is a ratio that shows the amount of debt compared to assets owned by a company. This ratio can be a benchmark in seeing the opportunistic behavior of managers in earnings management, in accordance with what Watts and Zimmerman (1986) stated that one of the motivations of management in earnings management is due to the emergence of a debt covenant hypothesis.

Several studies on women's membership in the structure of a company have been carried out and have produced mixed results. Peni and Vahaama (2010) and Gavious, et al (2012) state that the presence of one of the female CEOs or female CFOs will reduce the level of earnings management. Whereas Barua, et al (2010) stated that female CFO had a negative effect on earnings management while female CEOs did not have a significant influence.

Thiruvadi and Huang (2011) study analyzed the effect of the number of women in the audit committee and the number of men in the audit committee on the level of earnings management. The study reported that the presence of women in audit committee membership had a negative effect on earnings management. But in contrast to Khakim's (2014) study with a sample of public companies in Indonesia examining the influence of female CEOs, female CFOs, female commissioners, women's audit committees on real earnings management and accrual earnings management. The results of the study contradicted previous studies. Although there are results that female CFOs have a significant negative effect on earnings management, both accrual earnings management and real earnings management, this study also reports that the position of female CEOs, female commissioners, and female audit 
committees affect earnings management both accrual earnings management and management real profit is not significant.

Based on the description above which shows different results, the authors are interested in re-researching the factors that influence earnings management. This research is a development of Peni and Vahamaa's research (2010) by adding female board commissioner variables and women's audit committee and company size and leverage. To strengthen the research model, the authors also use control variables namely loss and sales growth. Based on the background stated above, the title in this study is "The Effect of Corporate Governance, Company Size and Leverage on Earnings Management".

\section{Study of Literature and Hypothesis Development}

\section{Agency Theory}

Jensen and Meckling (1976) explained that agency relations occur when one or more people (principals) employ other people (agents) to provide a service and then delegate decision-making authority. Principals are shareholders or investors, while agents are management who manage the company or manager. The core of the agency relationship is the separation of functions between investor ownership and management control.

\section{Signalling Theory}

Signaling Theory was first developed by Ross (1977). Signaling theory explains that a good financial report is a signal or a sign that the company has also operated well. Managers are obliged to give signals about the condition of the company to the owner as a form of responsibility for the management of the company. Signal theory explains why companies have the urge to provide financial report information to external parties. Information or stakeholders (Oliveira et al., 2006).

\section{Positive Accounting Theory}

Positive accounting theory explains the factors that influence management in choosing the best accounting procedure with a specific purpose. According to the Positive accounting theory proposed by Waats \& Zimmerman (1986), companies must be given the freedom to choose one of the alternative procedures to minimize contract costs and maximize company value. There is freedom for the manager to choose the accounting procedure, the manager has a tendency to carry out an action which is called positive earnings management by profit with the aim of benefiting him.

\section{Earnings Management}

Earnings management is the intervention of management in the process of preparing financial statements whose purpose is to be reported to external parties with specific objectives. Earnings management can reduce the credibility of financial statements because it does not reflect the actual condition of the company. Users of financial statements are likely to make wrong decisions because they get wrong financial information (Setiawati and Na'im, 2000).

\section{Corporate Governance}

According to the International Finance Corporation (IFC) (2014), defining Corporate Governance is "the structure and process for company direction and control. Corporate corporate governance is a system of relationships, defined by structure and process: For example, the relationship between shareholders, management and stakeholders consists of the relationship between capital providers and management to achieve certain returns and profits on their investments.

\section{Gender}

Gender according to the Women 's Studies Encyclopedia is a cultural concept used to distinguish the roles, behaviors, mentality, and emotional characteristics between men and women that develop in society (Mulia, 2004). From the definition above it can be understood that gender is a trait that is used as a basis for identifying differences between men and women in terms of social and cultural conditions, values and behavior, mentality, emotions, and other nonbiological factors

\section{Leverage}

Leverage is the use of fixed costs in an effort to increase profitability. A lever is used appropriately, so the pressure applied to one point will be formed or enlarged to a pressure or other point movement. Leverage affects the level and variability of after-tax income which further affects the overall level of risk and return of the company. The greater the level of leverage means the level of uncertainty of high returns, 
but on the other hand the amount of return given will be even greater (Van Horne et al., 2007).

\section{Pengembangan Hipotesis}

Effect of the Women's Board of Commissioners on Earnings Management.

The National Committee on Governance Policy (KNKG), states that the board of commissioners as a corporate organ is collectively responsible and responsible for supervising and advising the directors and ensuring that the company carries out good corporate governance. The nature of women who are more conservative, risk averse, and have a higher ethical standard is one of the factors that can be a cause of a negative relationship between the presence of women in the board of commissioners and earnings management. Krishnan and Parsons (2008) and Emadi and Mansour (2015) research show that the presence of women with more numbers in the top management ranks is associated with lower levels of earnings management. From the description, the following hypothesis is formulated:

\section{H1: The presence of women in the board of directors affects earnings management.}

\section{Effect of Women's Board of Directors on Earnings Management}

The Board of Directors is the organ of the company authorized and fully responsible for managing the company for the benefit of the company, in accordance with the goals and objectives of the company and representing the company, both inside and outside the court in accordance with the provisions of the articles of association. Research conducted by Gavious, et al (2012) shows that the presence of one of the women on the board of directors is significantly related to the lower level of earnings management. The research also shows that companies with a greater number of female representatives in their corporate governance or in their top management ranks will have higher earnings quality. From the description, the following hypothesis is formulated:

H2 : The presence of women in the board of directors affects earnings management.

\section{Effect of the Women's Audit Committee on Profit Management}

The Indonesian Audit Committee Association (IKAI) defines the audit committee as a committee that works professionally and independently assisted by the board of commissioners. Thus, the audit committee has the task of assisting and strengthening the function of the board of commissioners in carrying out the supervisory function of the financial reporting process, risk management, audit implementation and implementation of corporate governance. Thiruvadi and Huang (2011) research shows that the existence of female members in the audit committee will reduce the level of earnings management by the company, so that the fourth hypothesis is stated as follows.

H3 : The presence of women in the audit committee affects earnings management.

\section{Effect of Company Size on Earnings Management}

The size of the company shows the experience and ability of a company to grow in managing the investments invested by shareholders. Company size can be proxied by total assets, total sales, and market capitalization. Guna and Herawaty (2010) stated that companies that have large assets invest large amounts of capital, large sales make a large amount of money in large companies, and large market capitalization shows that the company is increasingly known to the public. The research of Siregar and Utama (2005) shows that firm size has a significant negative effect on earnings management, the smaller the company, the greater the earnings management. Based on the description, the proposed hypothesis is as follows:

\section{H4 : Company size affects earnings management}

\section{Effect of Leverage on Earnings Management}

Research conducted by Welvin and Arleen (2010) shows the results that leverage has a positive effect on earnings management, high leverage shows that the risk faced by investors is higher so that investors will ask for greater profits, it motivates managers to make earnings management. Other research results conducted by Indriani (2010) concluded that leverage does not affect earnings management because high debt policies cause the company to be monitored by debtholders so that managers act in the interests of debtholders and shareholders. From the explanation above, the hypothesis proposed in this study is:

H5 : Leverage affects earnings management 
Based on the hypothesis stated above, the hypothesis model in this study is as follows:

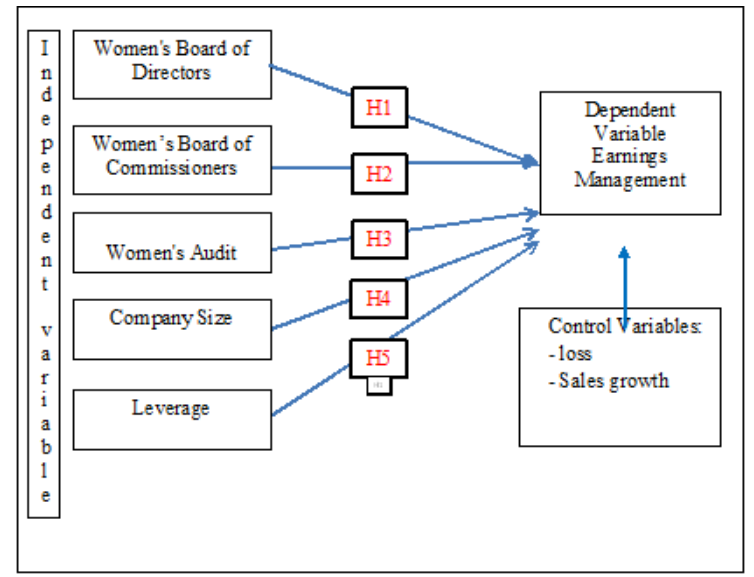

Picture 1. Research Objects

\section{Research Methods}

\section{Types and Data Sources}

The type of data used in this study is secondary data. Secondary data needed in this study are the audited financial statements of companies in 2012-2016 on public companies listed on the Indonesia Stock Exchange. Secondary data collected is obtained through the www.idx website. co.id

\section{Variable Operational Definition and Measurement}

\section{Dependent Variables}

The dependent variable in this study is earnings management as measured by proxy discretionary accruals (DA). The measurement of discretionary accruals is done by using the Jones (1991) Model modified by Dechow et. al. (1995). This model is used because it can detect earnings management consistently (Guna and Herawaty 2010). The Modified Jones Model uses total accruals (TA) which are classified as components of discretionary accruals (DA) and non-discretionary accruals (NDA).

\section{Independent Variable}

The independent variable is a variable that affects the dependent variable positively or negatively. The independent variable used in this study is corporate governance, namely female membership in the board of directors, board of commissioners and audit committee.

\section{Women's Board of Directors}

According to Puspitasari (2014) the board of directors is a position that comes from English which has the highest executive position. The task of a board of directors is to lead and take full responsibility for the performance of the company he leads. In this study, the female board of directors is the presence of women in the board of directors. The variable size of the female board of directors is calculated using a percentage of the number of female directors to the total number of directors.

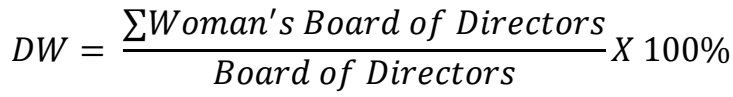

\section{Women's Board of Commisioners}

The board of commissioners is a board that is responsible for supervising and advising the director. Members of the board of commissioners are appointed and dismissed with the approval of members of the General Meeting of Shareholders (GMS) which are then reported to the Minister of Law and Human Rights to be listed in the mandatory list of companies for the replacement of the board of commissioners. The appointment of the board of commissioners is proposed by members of the GMS who have the authority to propose the board of commissioners. KW

$$
=\frac{\sum \text { Woman's Board of Commissioners }}{\text { Board of Commissioners }} \times 100 \%
$$

\section{Women's Audit Committee}

The audit committee is a group of people who are chosen by a larger group to do certain work or to do special tasks or a number of commissioners of a client company who are responsible for assisting the auditor in maintaining its independence from management (Puspitasari, 2014). In this study, the women's audit committee is the presence of women in the composition of the audit committee members. The variable size of a women's audit committee is calculated using a percentage of the number of women's audit committees on the total number of audit committees.

$$
A W=\frac{\sum W \text { oman's Audit Committe }^{\prime}}{\text { Audit Committe }} \times 100 \%
$$

\section{Company Size}

Definition of company size according to Riyanto 
(2008), The size of the company is seen from the value of the equity, the total value of the sale, or the value of the total assets. The size of the company in this study is proxied by total assets, with consideration because the company's total assets are relatively more stable compared to the number of sales and market capitalization of Siregar and Utama (2005). Company size is measured by using the results of the logarithm of the total assets with the following formula:

UKR : Ln Total Assets

\section{Leverage}

Leverage is a comparison between debt and assets that shows some parts of assets used to guarantee debt. Companies that have a higher likelihood of violating debt agreements, the company tends to do earnings management to increase company profits. This variable will be represented by LEV in the equation based on Siregar and Utama's (2005) research.

$\mathrm{LEV}=$ Total Ammount of Debt/total assets

\section{Control Variables}

Control variables in this study use loss and sales growth. Previous research shows that the characteristics of the company above are useful predictors of earnings management.

\section{Sample}

\section{Object of research}

The object of this study is a manufacturing company listed on the Indonesia Stock Exchange (IDX) for the period 2012-2016. This study uses secondary data, therefore the technique of determining the number of samples in this study the authors use the total sampling technique using purposive sampling method. The data collection technique of this research is archival data collection techniques in the database, through the Indonesia Stock Exchange website, www.idx.co.id and the official website of the company that is the object of research. The data obtained is secondary data. The study uses panel data starting from 2012-2016.The criteria used are as follows: (a) Manufacturing companies listed on the Indonesia Stock Exchange during the period 2012-2016. (B) Manufacturing companies that publish financial reports and annual reports (annual reports) during the period 2012-2016. (c) Not including companies that do delisting (d) Financial reports are published using rupiah units in their presentation. (e) Having complete data related to variables determined by the author to be examined.

\section{Data Processing Techniques}

The panel data processing technique used in this study is regression analysis using Eviews version 10 . Several stages are used in this study, first is editing, by checking the data that has been collected so that the data is in accordance with the research objectives. The second stage is data tabulation, by entering data into tables that have been labeled according to the analysis required. The last stage is processing data statistically using Eviews version 10 data processing application.

\section{Data analysis technique}

\section{Descriptive Statistical Analysis}

Descriptive statistical analysis is an analysis used to analyze data by describing or describing data that has been collected as it is without intending to make generally accepted conclusions or generalizations (Sugiyono, 2014). Descriptive analysis in this study presents minimum values, maximum values, mean values, and standard deviations.

\section{Multiple Linear Regression Analysis}

Multiple linear regression analysis of panel data is used to determine the direction of the relationship between the variables of the female board of commissioners, the female board of directors, the board of the female audit committee, company size and leverage on earnings management. Regression models developed to test the hypotheses that have been formulated in this study are:

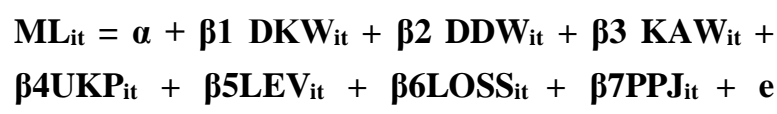
In this case are:
a
$=$ Constants
$\mathrm{ML}=$ Profit Management
DKW = Board of Commissioners for Women
DDW = Women's Board of Directors
KAW = Women's Audit Committee
UKP = Company Size
Lev $\quad=$ leverage 


$$
\begin{array}{ll}
\text { LOSS } & =\text { Loss } \\
\text { PPJ } & =\text { Sales Growth }
\end{array}
$$

$\beta 1, \beta 2, \beta 3, \beta 4, \beta 5=$ Regression coefficients for DKW, DDW, KAW, UKP, and LEV

$\varepsilon=$ error term

\section{Determination Coefficient Test (R2)}

The determination coefficient test aims to measure the extent to which independent variables can explain variations in the dependent variable, both partially and simultaneously. The value of this determination coefficient is between zero and one $(0$ $<$ R2 <1). According to Ghozali (2013), a small R2 value means that the ability of independent variables in explaining the variation of the dependent variable is very limited. Conversely, if the R2 value which is close to 1 (one) means that the independent variable provides almost all the information needed to predict the variation of the independent variables.

\section{Goodness of Fit Test (Test F)}

The Goodness of Fit test or it can be called the F Test is used to test whether there is an influence of all independent variables on the dependent variable as a whole. If the significance value $<$ from 0.05 means that the research model is used significantly in predicting the dependent variable and if the significance value $>0.05$ means that the research model used is not significant in predicting the dependent variable.

\section{T Test}

The $t$ test aims to show whether the independent variables used in the study affect earnings management. In other words, the T Test can be used to take hypothetical decisions by looking at the significance number. The testing criteria are:

1. Ho is accepted if Pvalue $>a=0.05$

Means that the independent variable does not affect the dependent variable.

2. Ho is rejected if Pvalue is $<\mathrm{a}=0.05$

Means that the independent variable influences the dependent variable.

\section{Result and Discussion}

The object of this study is a manufacturing company listed on the Indonesia Stock Exchange (IDX) for the period 2012-2016. Company samples are determined based on predetermined criteria. Based on this, the number of samples used in this study can be seen in Table 4.1.

Table 4.1 Sample Criteria

\begin{tabular}{ll}
\hline Sample Criteria & Qty \\
\hline $\begin{array}{l}\text { Total Sample Criteria Manufacturing } \\
\text { companies registered during 2012-2016 }\end{array}$ & 785 \\
\hline Companies that experienced delisting & $(285)$ \\
\hline Companies that do not use rupiah & $(150)$ \\
\hline $\begin{array}{l}\text { Companies that have incomplete financial } \\
\text { statement }\end{array}$ & $(125)$ \\
\hline $\begin{array}{l}\text { Have complete data related to research } \\
\text { variables } \\
\text { (45 companies multiplied by 5 years) }\end{array}$ & $\mathbf{2 2 5}$ \\
\hline
\end{tabular}

Source: Data Processed, 2018

Based on Table 4.1 can be seen the number of samples selected based on certain criteria. The number of manufacturing companies listed on the Indonesia Stock Exchange for 2012-2016 totaled 785 companies. During the study period there were 285 companies that experienced delisting. There are 150 companies that do not use rupiah currency. Companies that do not display the complete research variables and information needed are 125 companies, so the number of companies that are sampled in this study is 225 companies in the 5-year study period.

Detection of outlier data is done by converting data values into standardized (z-scored) scores, for a large sample the standard score is declared an outlier if it has a Z-Score $>3$ or $<-3$ (Ghozali, 2013). The value of $z$-score from the initial research sample stated outlier can be seen in table 4.2.

Table 4.2 Data Outliers

\begin{tabular}{lll}
\hline No & Company Name & Stock Code \\
\hline 1 & Arwana Citramulia Tbk. & ARNA \\
\hline 2 & Duta Pertiwi Nusantara Tbk. & DPNS \\
\hline 3 & Gudang Garam Tbk. & GGRM \\
\hline 4 & Kabelindo Murni Tbk. & KBLM \\
\hline 5 & Mustika Ratu Tbk. & MRAT
\end{tabular}

Source: Author 
After detection of outlier data, it was found that based on 225 initial sample data on each variable, there were 5 companies that had outlier data. Outlier data is excluded from testing and not included, so that the total data to be used is 200 sample data.

\section{Descriptive statistics}

The results of data processing using Eviews version 10 for descriptive statistics describe the mean, maximum, minimum, and standard deviation of the dependent variable (Y) and the independent variable (X) presented in table 4.1. below this.

\begin{tabular}{|c|c|c|c|c|c|}
\hline Variabel & Mean & Maximum & Minimum & Std. Dev. & N \\
\hline ML & 0,001 & 0,020 & $-0,042$ & 0,006 & 200 \\
\hline DKW & 0,137 & 0,670 & 0,000 & 0,182 & 200 \\
\hline DDW & 0,140 & 0,750 & 0,000 & 0,195 & 200 \\
\hline KAW & 0,247 & 0,670 & 0,000 & 0,255 & 200 \\
\hline UKP & 26,490 & 28,842 & 19,957 & 2,081 & 200 \\
\hline LEV & 0,502 & 12,579 & 0,000 & 1,316 & 200 \\
\hline LOSS & 0,065 & 1,000 & 0,000 & 0,247 & 200 \\
\hline PPJ & 16,022 & 1051,774 & $-0,986$ & 85,624 & 200 \\
\hline
\end{tabular}

Source: Output Eviews 10, 2018 (Data Processed)

\section{Model Data Panel Selection}

\section{ChowTest}

Chow test is done to compare or choose the best regression model between Common Effect Model (CEM) and Fixed Effect Model (FEM) by using F test (chow test), where the significance level is 0.05 .

Table 4.6 Chow Test

Redundant Fixed Effects Tests

Test cross-section fixed effects

\begin{tabular}{|l|r|r|r|}
\hline Effects Test & Statistic & d.f. & Prob. \\
\hline Cross-section F & 1.537 & $(39,153)$ & 0.035 \\
\hline Cross-section Chi-square & 66.127 & 39 & 0.004 \\
\hline
\end{tabular}

Source: Output Eviews 10, 2018 (Data Processed)

Based on the table above, the cross-section probability value of $\mathrm{F}$ is 0.035 . The cross-section $\mathrm{F}$ probability value is $<0.05$ so the results of the Chow test show that the Fixed Effect Model (FEM) is more appropriate to be used compared to the Common Effect Model (CEM), then the Hausman test will be carried out.

\section{Hausman Test}

Hausman test is done to compare or choose the best model between Fixed Effect Model (FEM) and Random Effect Model (REM) by using Hausman test, where the significance level is 0.05
Table 4.7. Hausman Test

\begin{tabular}{|l|r|r|r|}
\hline \multicolumn{3}{|l|}{ Correlated Random Effects - Hausman Test } \\
\hline Test cross-section random effects \\
\hline Test Summary & Chi-Sq. Statistic & Chi-Sq. d.f. & Prob. \\
\hline Cross-section random & 8.738 & 7 & 0.272 \\
\hline
\end{tabular}

Source: Output Eviews 9, 2018 (Data Processed)

The magnitude of the probability value of the random cross-section in the table above is 0.272 . The probability value of the random cross-section is $>0.05$, then the results of the Hausman test show that Random Effect Model (REM) is more appropriate to use than the Fixed Effect Model (FEM).

\section{Lagrange Multiplier Test}

The Lagrange Multiplier test is done to compare or choose the best model between Random Effect Model (REM) and Common Effect Model (CEM) by using the Lagrange Multiplier test, where the significance level is 0.05 .

Table 4.7. Lagrange Multiplier Test

\begin{tabular}{|l|c|c|c|}
\hline \multicolumn{4}{|l|}{ Lagrange Multiplier Tests for Random Effects } \\
\hline \multicolumn{4}{|c|}{ Test Hypothesis } \\
\hline & Cross-section & Time & Both \\
\hline & 1.510 & 1.116 & 2.627 \\
\hline Breusch-Pagan & $(0.219)$ & $(0.290)$ & $(0.015)$ \\
\hline
\end{tabular}

Sumber: Output Eviews 10, 2018 (Data Diolah)

From the results of the Lagrange Multiplier Test above, the magnitude of Breusch-Pagan's cross-section probability is 0.015 . The probability value is $<0.05$ so the decision taken is Random Effect Model (REM is better used than the CEM Common Effect Model).

Based on the results of the Chow test, the Hausman test and the Lagrange Multiplier test, the chosen model is Random Effect Model (REM) so that the classical assumption test (multicollinearity, heteroscedasticity and autocorrelation) does not need to be done because Random Effect Model (REM) uses the Generalized Least Square (GLS) method. ) (Sedyadi, 2014).

\section{Multiple Regression Analysis}

Multiple linear regression analysis of panel data is used to determine the direction of the relationship between the variables of the female board of commissioners, the female board of directors, the board of the female audit committee, the size of the 
company and leverage on Profit Management in manufacturing companies listed on the Indonesia Stock Exchange in 2012-2016. The results of data processing with Eviews version 10 are presented in table 4.9.

Table 4.9. Multiple Linear Regression Panel Data

\begin{tabular}{|c|r|r|r|}
\hline Variable & \multicolumn{1}{|c|}{ Coefficient } & \multicolumn{1}{c|}{ t-Statistic } & \multicolumn{1}{c|}{ Prob. } \\
\hline C & 0.0008 & 0.112 & 0.910 \\
\hline DKW (H1) & 0.0009 & 0.214 & 0.830 \\
\hline DDW (H2) & $-0,0148$ & $-2,467$ & 0.014 \\
\hline KAW (H3) & 0.0035 & 0.958 & 0.339 \\
\hline UKP (H4) & 3.3400 & -0.612 & 0.907 \\
\hline LEV (H5) & $-0,0003$ & -0.612 & 0.541 \\
\hline LOSS & 0.0014 & 0.695 & 0.488 \\
\hline PPJ & -4.1012 & -0.717 & 0.474 \\
\hline
\end{tabular}

Sumber: Output Eviews 10, 2018 (Data Diolah)

Based on the results of multiple linear regression processing panel data in table 4.9. above, obtained the equation model as follows:

$$
\begin{gathered}
\mathrm{ML}_{\mathrm{it}}=\alpha+\beta 1 \mathrm{DKW}_{\mathrm{it}}+\beta 2 \mathrm{DDW}_{\mathrm{it}}+\beta 3 \mathrm{KAW}_{\mathrm{it}}+\beta 4 \mathrm{UKP}_{\mathrm{it}}+ \\
\beta 5 \mathrm{LEV}_{\mathrm{it}}+\beta 6 \mathrm{LOSS}^{+\beta 7 \mathrm{PPJ}_{\mathrm{it}}}
\end{gathered}
$$

The regression equation above can be interpreted as follows:

a. In the equation above, the constant coefficient $(\alpha)$ is 0.0008 , indicating that if the independent variable is 0 , there will be earnings management of 0.0008 .

b. Regression coefficient for female commissioner variable (DKW) is 0,0009 , indicating that every increase in one level of the female commissioner variable assuming other variables remain, will increase earnings management by 0,0009 units.

c. Regression coefficients for female board of directors (DDW) variables of -0.0148 indicate that for every increase in one level of the female board of directors assuming other variables remain, it will decrease earnings management by 0.0148 units.

d. Regression coefficients for the female audit committee council variable (KAW) of 0.0035 indicate that every increase in the level of the female audit committee council variable assuming other variables remain, will increase earnings management by 0.0035 units. e. Regression coefficient for firm size variable (UKP) of 3.3400 shows that every increase in one level of the company size variable assuming other variables remain, will increase earnings management by 3.3400 units.

f. Regression coefficients for leverage variables (LEV) of -0,0003 indicate that for each increase in one level of the leverage variable assuming other variables remain, it will reduce earnings management by 0.0003 units.

g. Regression coefficients for variable loss of 0.0014 indicate that every increase in one level of the loss variable assuming the other variables remain, will increase earnings management by 0.0014 units.

h. Regression coefficient for sales growth variable (PPJ) of -4.1012 shows that every increase in one level of the sales growth variable assuming other variables remain, will reduce earnings management by 4.1012 units.

i. Standard error (e) is a random variable and has a probability distribution that represents all the factors that have an effect on Y but are not included in the equation.

\section{Goodness of Fit Test}

F test (simultaneous) is conducted to test whether the independent variables, namely the female board of commissioners, the female board of directors, the female audit committee board, company size and leverage simultaneously (together) have an influence on the dependent variable earnings management. The $\mathrm{F}$ test output with Eviews version 10 can be seen in table 4.14 .

Table 4.14 F Test

\begin{tabular}{ll}
\hline F-statistic & 1,3526 \\
\hline Prob(F-statistic) & 0,0897 \\
\hline
\end{tabular}

From table 4.14 shows the results of the statistical test $\mathrm{F}$ has a probability value of 0.089 greater than 0.005 . So it can be concluded that all independent variables, namely, the female board of directors, the female board of commissioners, the female audit committee board, company size and leverage simultaneously do not affect the dependent variable namely earnings management. 


\section{Hypothesis (t Test)}

The $t$ test is done by comparing the values of tcount and $t$ table, and comparing the significance value. The results of the $t$ test are shown in the following table:

Table 4.12. T Test
\begin{tabular}{|c|r|r|r|r|}
\hline & & & & \\
Variable & Coefficient & Std. Error & t-Statistic & \multicolumn{1}{c|}{ Prob. } \\
\hline C & 0.0008 & 0.007 & 0.112 & 0.910 \\
\hline DKW & 0.0009 & 0.004 & 0.214 & 0.830 \\
\hline DDW & $-0,0148$ & 0.006 & $-2,467$ & 0.014 \\
\hline KAW & 0.0035 & 0.003 & 0.958 & 0.339 \\
\hline UKP & 3.3400 & 0.000 & -0.612 & 0.907 \\
\hline LEV & $-0,0003$ & 0.000 & -0.612 & 0.541 \\
\hline LOSS & 0.0014 & 0.002 & 0.695 & 0.488 \\
\hline PPJ & -4.1012 & 5.720 & -0.717 & 0.474 \\
\hline
\end{tabular}

Sumber: Output Eviews 10, 2018 (Data Diolah)

Based on Table 4.12 it is known that the value of ttable at the $5 \%$ significance level can be calculated as follows: Table value with the number of samples $(\mathrm{n})=$ 200 , the number of variables $X(k)=5$, significance level $\alpha=5 \%$ and degree of freedom $(\mathrm{df})=\mathrm{nk}-1$ $(200-5-1=194)$, is \pm 1.972 . Based on the output above, testing the hypothesis in this study can be described as follows with the value of $t$ table at a significant level of $5 \%$ or 0.05 and df (degree of freedom) or t table $n-k-1$ $=194$ is \pm 1.972 .

\section{Koefisien Determinasi Test $\left(\mathbf{R}^{2}\right)$}

The coefficient of determination is a coefficient that shows the percentage of all the effects of the independent variable on the dependent variable. This percentage shows how much the independent variable can explain the dependent variable. The greater the coefficient of determination, the better the independent variable explains the dependent variable. The coefficient of determination can be seen in the following Table 4.15:

Tabel 4.15 Koefisien Determinasi

\begin{tabular}{|l|l|}
\hline Adjusted R-squared & 0,0753 \\
\hline
\end{tabular}

Sumber: Output Eviews 10, 2018 (Data Diolah)

The results of this test indicate that the Ajusted R2 value is 0.0753 . This value can be interpreted that the female commissioner variables, the female board of directors, the female audit committee board, company size and leverage affect the stock price by $7.53 \%$ while the remaining $92.47 \%$ is influenced by other factors not examined in this study.

\section{Data analysis}

\section{Effect of the Women's Board of Commissioners on Earnings Management}

From the results of the research conducted, it is known that the female board of commissioners variable has no effect on earnings management in manufacturing companies listed on the Indonesia Stock Exchange (BEI) in 2012-2016. The influence of the female board of commissioners in this study was not because the existence of the board of commissioners in the structure of the company structure did not all take part in managing the company's earnings.

This result is consistent with the research conducted by Thiruvadi and Huang (2011) which states that female board of commissioners have no effect on earnings management, in contrast to research conducted by Khakim's (2014) research which states that the board of directors influences earnings management. It can be concluded that not all commissioners participate in the company's profit management activities.

\section{Effect of the Women's Board of Directors on earnings management}

Based on the results of the study it can be seen that the variable of the female board of directors influences earnings management in manufacturing companies listed on the Indonesia Stock Exchange (BEI) in 2012-2016. The influence of the female board of directors in this study is due to a responsibility of a director as a leader in managing corporate earnings management.

The results of this study are in line with the research conducted by Peni and Vahaama (2010) which states that female directors have a significant effect on earnings management, in contrast to the results of research conducted by Barua, et al (2010) which mentions the female board of directors has no significant effect on profit management. It can be concluded that the responsibility of a board of directors as a company leader is influential in managing company earnings. 


\section{Effect of the Women's Audit Committee on Profit}

\section{Management}

From the results of the research conducted, it is known that the female audit committee council variable does not affect earnings management in manufacturing companies listed on the Indonesia Stock Exchange (BEI) in 2012-2016. The audit committee board has no influence in this research because the audit committee board is more focused on assisting the auditor in maintaining his independence to management.

The results of this study are in line with research conducted by Thiruvadi and Huang Research (2011) which states that the audit committee board has no significant effect on earnings management, in contrast to the research conducted by Gavious, et al (2012) which states that the audit committee council has a significant influence on profit management. This can be concluded that the audit committee board does not have a significant influence in earnings management.

\section{Effect of Company Size on Earnings Management}

Based on the results of the study, it can be seen that the company size variable does not affect earnings management in manufacturing companies listed on the Indonesia Stock Exchange (BEI) in 2012-2016. This shows that the size of the company is not necessarily able to reduce the likelihood of earnings management, because large companies have large or large total assets tend to be more publicly highlighted compared to small companies that have small total assets. The greater the company will tend to reduce earnings management, because large companies are politically more attention from the government and society compared to small companies. The results of this study are not in line with the research conducted by Siregar and Utama (2005) the size of the company consistently has a significant negative effect on the amount of earnings management by the company, in contrast to the research conducted by Barua, et al (2010) which states that the size of the company giving a positive influence on earnings management.

\section{Effect of Leverage on Earnings Management}

From the results of research conducted, it is known that the leverage variable does not affect earnings management in manufacturing companies listed on the Indonesia Stock Exchange (BEI) in 2012-2016. Leverage is the use of fixed costs in an effort to increase profitability. A lever is used appropriately, so the pressure applied to one point will be formed or enlarged to a pressure or other point movement. Leverage affects the level and variability of after-tax income which further affects the overall level of risk and return of the company. The greater the level of leverage means the level of uncertainty of high returns, but on the other hand the amount of return given will be even greater (Van Horne et al., 2007).

This research is in line with the research conducted by Siregar and Utama (2005) which states that leverage has a significant positive effect on earnings management, in contrast to research conducted by Peni and Vahaama (2010) leverage has no significant influence on earnings management.

\section{Penutup}

\section{Conclusion}

Based on the results of the analysis of the influence of the variables of the female board of commissioners, female board of directors, women's audit committee, Company Size, Leverage, to earnings management with loss and sales growth as control variables in companies listing on the Indonesia Stock Exchange in 2012-2016 can be concluded as follows:

1. The results of testing the first hypothesis found that the female board of commissioners had no effect on earnings management. This means that it can be concluded that not all commissioners participate in corporate earnings management activities.

2. The results of testing the second hypothesis find that the female board of directors influences earnings management. This means that it can be concluded that the responsibility of a board of directors as a company leader is influential in the company in managing earnings.

3. The results of the third hypothesis testing found that the female audit committee had no effect on earnings management. The ineffectiveness of the 
women's audit committee is due to the fact that the audit committee board does not have a significant influence on earnings management.

4. The fourth test results found that the size of the company does not affect earnings management. The ineffectiveness of the size of the company in this study states that the size of the company is often regarded as a signal to investors in assessing the good and bad of a company, this is because the assessment cannot have a significant influence on the company in earnings management.

5. The fifth test results find that leverage affects earnings management. This means that the higher the use of fixed costs in an effort to increase profitability affects the company in earnings management.

\section{Limitations}

This research still has many limitations that might influence the results of research, including:

1. The number of samples is still small when compared to the population of companies listed on the Indonesia Stock Exchange.

2. In this study there are some incomplete or not available data, so it must reduce the number of samples.

3. Proxy used for measuring earnings management in this study Measuring total accruals using Modified Jones Model (TA = NIit CFOit), Calculating the total value of accruals with Ordinary Least Square (OLS) equations with the equation: (1) Tait / Ait $-1=\alpha 1(1 /$ Ait -1$)+$ $\alpha 2(\triangle \mathrm{REVit} / \mathrm{Ait}-1)+\alpha 3$ (PPEit / Ait -1$)+\varepsilon i t)$.

(2) By using the regression coefficient above, then the calculation of the value of non discretionary accruals (NDA) can be formulated as follows: $($ NDAit $=\alpha 1(1 /$ Ait -1$)+\alpha 2((\triangle$ REVit $\triangle$ RECit) / Ait - 1) $+\alpha 3$ (PPEit / Ait -1$)$ ), Calculates the value of the discretionary accruals with the equation: $($ DAit $=($ Tait $/$ Ait -1$)$ NDAit).

4. Further research should be able to use other earnings management proxies if data is available.

\section{Research Implication}

This research can be used as reference material or additional information for further research that examines the timeliness of the submission of financial statements. This research can also be a reference for managers and investors so that later the company can measure the company's ability to fulfill compliance in the delivery of financial statements

\section{Suggestions for Further Researchers}

Based on the results of the research, the suggestions that can be given are:

1. Increase the research period. In this study the research period used is relatively short, therefore for further research it is expected to extend the research period in order to see trends in the long term.

2. Adding variations to the independent variables so that the effect can be seen clearly in earnings management, such as market to book value ratio, ownership structure, and CETR / ETR and add other variables related to earnings management.

3. Earnings management is the intervention of management in the process of preparing financial statements whose purpose is to be reported to external parties with a specific purpose. Earnings management can reduce the credibility of financial statements because it does not reflect the actual condition of the company.

4. Research results are expected to contribute to academics in developing future research, and can be used as reference material for research.

\section{Reference}

Albrecth, W. D. and F.M., Richardson. 1990. Income Smoothing by Economy Sector. Journal of

Business Finance and Accounting 17 (5)

Winter.

Ariefianto, M. D. (2012). Ekonometrika: Esensi dan

Aplikasi dengan Menggunakan Eviews.

Jakarta: Penerbit Erlangga.

Arifin. 2005. "Peran Akuntan Dalam Menegakkan

Prinsip Good Corporate Governance Pada

Perusahaan Di Indonesia (Tinjauan

Perspektif Teori Keagenan)”. Semarang :

Universitas Diponegoro.

Barua, A., L. F. Davidson, D. V. Rama, dan S.

Thiruvadi. (2010). CFO gender and accruals quality. Accounting Horizons. 
Belkaoui, Ahmad Riahi. (2006). Accounting Theory. Jakarta: Salemba Empat.

Brigham, Eugene dan Joel Houston. (2006).

“Manajemen Keuangan”. Jakarta: Salemba Empat.

Darmawati, Khomsiyah dan Rahayu. 2004.

"Hubungan Corporate Governance dan Kinerja Perusahaan”. Simposium Nasional Akuntansi (SNA) VII Denpasar.

Dechow, P. M., R. G. Sloan dan A. P. Sweeney. (1995). Detecting earnings management. The Accounting Review.

Emadi, G dan G. Mansour. (2015). The Association Presence of Female Members on the Board of Directors and Earnings Management With Discretionary Accruals Indexion the Listed Companies in Tehran Stock Exchange. Jurnal of Current Research in Science 3 (1): 39-43.

Fakih, M. (2006). Analisis Gender dan Transformasi Sosial. Yogyakarta: Pustaka Pelajar.

Gavious I., E. Segev dan R. Yosef. (2012). Female Directors and Earnings Management in High Technology Firms. Pacific Accounting Review

Ghozali, Imam. 2013. Aplikasi Analisis Multivariate dengan Program SPSS. Edisi Ketujuh. Semarang : Badan Penerbit Universitas Diponegoro.

Gujarati, Damodar, 2006, Dasar-dasar Ekonometrika, Edisi ke tiga, Jilid Penerbit Erlangga, Jakarta

Healy, Paul. M; James M. Wahlen. (1998). A review Of

The Earnings Management Literature And Its Implications For Standart Setting.

Herni dan Susanto, Yulius. 2008. "Pengaruh Struktur Kepemilikan Publik, Praktik Pengelolaan Perusahaan, Jenis Industri, Ukuran Perusahaan, Profitabilitas dan Risiko Keuangan terhadap Tindakan Perataan Laba (Studi Empiris pada Industri yang Listing di Bursa Efek Jakarta)”. Jurnal Ekonomi dan Bisnis Indonesia Vol 23 No 3.
IFC (International Finance Corporation). (2014). “The Indonesia Corporate Governance Manual: First Edition," Jakarta. hlm. 30

Indriani, Yohana. 2010. Pengaruh Kualitas Auditor, Corporate Governance, Leverage dan Kinerja Keuangan Terhadap Manajemen Laba. Skripsi Universitas Diponegoro: Semarang.

Jensen, Michael C dan William H Meckling. 1976. Theory of the Firm: Managerial Behaviour, Agency Cost, and Ownership Structure. Journal of Financial Economics, Vol. 3, No. 4, h. 305-360.

Jones, Jennifer J. 1991. Earnings Management During Import Relief Investigations. Journal of Accounting Research Vol.29 No.2.

Khakim. (2014). "Pengaruh Kompensasi Manajemen Eksekutif Terhadap Kinerja Keuangan Perusahaan". Jurnal Akuntansi Fakultas Ekonomi Universitas Negeri Surabaya. Vol. 4, No. 6, h. 43-46.

KNKG (Komite Nasional Kebijakan Governance). (2006). Pedoman Umum Good Corporate Governance Indonesia.

Krishnan, G. P. dan L. M. Parsons. (2008). Getting to the bottom line: an exploration of gender and earnings quality. Journal of Business Ethics.

Mansour, G dan G. Emedi. (2015). The Association Presence of Female Members on the Board of Directors and Earnings Management With Discretionary Accruals Indexion the Listed Companies in Tehran Stock Exchange. Jurnal of Current Research in Science 3 (1): 39-43.

Marzuki. (2006). Kajian awal tentang teori-teori gender. Universitas Negeri Yogyakarta.

Mulia, Siti Musda. (2004). Kekerasan tehadap Perempuan mencari Akar Kekerasan dalam teologi, SAWWA Jurnal Studi Gender dan Anak, Vol. 3, No. 1.

Mutmainah S. 2007. Studi Tentang Perbedaan Evaluasi Etis, Intensi Etis (Athical Intention) dan Orientasi Etis Dilihat dari Gender dan Disiplin Ilmu: Potensi Rekruitmen Staf Profesional pada Kantor Akuntan Publik. 
Jurnal Riset Akuntansi Indonesia Vol. 10:

43-67.

OECD (Organization for Economic Co-operation and Development) (2015). Principles of

Corporate Governance. Turkey: OECD. hlm. 4-6

Peni, E. dan S. Vahamaa. (2010). Female Executive and Earnings Management. Managerial Finance.

Puspitasari, C. (2014). Pengaruh Leverage,

Kepemilikan Institusional, dan Ukuran Perusahaan terhadap Penghindaran Pajak (Tax Avoidance) pada Perusahaan Sektor Manufaktur yang Terdaftar di Bursa Efek Indonesia 2010-2012. Jurnal Akuntansi, Vol 18, No 3, Halaman 408- 421.

Rahmawati, Andri dan Hanung Triatmoko. (2006). “Analisis Faktor-Faktor yang Mempengaruhi Kualitas Laba dan Nilai Perusahaan". Simposium Nasional Akuntansi X. Hal 1-26. Makasar.

Riyanto, Bambang. (2008). Dasar-dasar Pembelanjaan Perusahaan. Yogyakarta: Penerbit GPFE

Ross, S. A. (1977). The Determination of Financial Structure: The Incentive-Signalling Approach. The Bell Journal of Economics, 23-40.

Rustiarini, W. (2010). Komite Audit dan Kualitas Audit: Kajian Berdasarkan Karakteristik, Kompetensi, dan Aktivitas Komite Audit. Skripsi Universitas Mahasaraswati Denpasar. Saptantinah, Dewi Astuti. (2010). Analisis

Faktor-Faktor Yang Mempengaruhi Motivasi Manajemen Laba Di Seputar Right Issue. Simposium Nasional Akuntansi VIII, Solo.

Scott, R. William. 2013. "Financial Accounting

Theory". Toronto: Pearson Education Canada Inc.

Sedyadi, G. S. M. (2014). Kajian Pengaruh Desentralisasi Fiskal Asimetri Di Indonesia Terhadap Efisiensi Penyediaan Barang dan Layanan Publik Sektor Pendidikan. Skripsi. Institut Teknologi Bandung, Bandung.
Setiawati, Lilis dan Ainun Na'im. 2000. Manajemen

Laba , Jurnal Ekonomi dan Bisnis Indonesia, Vol 15, No. 4.

Siallagan, H., dan Mas'ud Machfoedz. 2006.

Mekanisme Corporate Governance, Kualitas laba dan Nilai Perusahaan. Makalah

Simposium Nasional Akuntansi IX.

Sihite, R. C. (2012). Pengaruh Gender Pada Dewan

Komisaris, Dewan Direksi dan Komite Audit Terhadap Profitabilitas dan Kualitas Laba

Perusahaan. Skripsi Tidak Diterbitkan.

Depok: Universitas Indonesia.

Siregar, P.N., Veronica, Sylvia dan Sidharta Utama. 2005. Pengaruh Struktur Kepemilikan, Ukuran Perusahaan dan Praktek Corporate Governance terhadap Pengelolaan Laba (Earnings Manajemen). Simposium Nasional Akuntansi VIII, Solo.

Sugiyono (2007). Statistik Untuk Penelitian. Bandung: Alfabeta, cv.

Sugiyono (2014). Metode Penelitian Bisnis. Cetakan Keenam Belas. Bandung: Alfabeta, cv.

Sulistiawan,D, Januarsi,Y, dan Alvia, L, 2011,

Creative Accounting, Mengungkap

Manajemen Laba dan Skandal Akuntansi,

Salemba Empat, Jakarta.

Sulistyanto,S, 2008. Manajemen Laba Teori dan Model Empiris, Grasindo, Jakarta.

Sujarweni, V. W. (2007). Belajar Mudah SPSS untuk Penelitian. Yogyakarta: Global Media Info.

Thiruvadi, S. dan H. Hua-Wei. (2011). Audit committee gender differences and earnings management, Gender in Management: $A n$ International Journal.

Van Horne, et al. (2007). Prinsip-Prinsip Manajemen Keuangan, Edisi 12. Jakarta: Salemba Empat.

Watts, R. L., and J. L. Zimmerman. 1986. Positive Accounting Theory. Englewood Cliffs, NJ: Prentice Hall, Inc.

Welvin, I Guna dan Herawaty, Arleen. 2010. "Pengaruh Mekanisme Good Corporate Governance, Independensi Auditor, Kualitas Audit dan Faktor Lainnya Terhdap 
Manajemen Laba". Jurnal Bisnis dan

Akuntansi Vol 12 No 1 April 2010 h. 53-68.

Wirawan, G. dan Y. Novialy. (2012). Indikasi

Manajemen Laba oleh Chief Executive

Officer (CEO) Baru pada

Perusahaan-Perusahaan yang Terdaftar di

Pasar Modal Indonesia. Jurnal Akuntansi dan

Bisnis 7(1).

Wolk, Harry I., Michael G. Tearney. and James.Dodo.

(2001). Accounting Theory, A Conceptual and

Institutional Approach. Fifth Edition,

South-Western College Publishing,Thomson

Learning. 